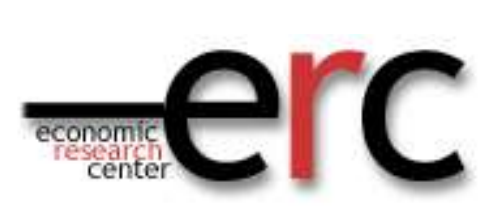

ERC Working Papers in Economics 15/05

August/ 2015

\title{
Southwest as the New Internal Migration Destination in Turkey
}

\author{
Ali T. Akarca \\ Department of Economics (mc 144), University of Illinois at Chicago, \\ 601 S. Morgan Street, Chicago, Illinois 60607, USA. \\ E-mail: akarca@uic.edu \\ Aysit Tansel \\ Department of Economics, Middle East Technical University, Ankara, Turkey and \\ Institute for the Study of Labor (IZA) Bonn, Germany and \\ Economic Research Forum (ERF) Cairo, Egypt \\ E-mail: atansel@ metu.edu.tr \\ Phone: + (90) 3122102073
}




\section{SOUTHWEST AS THE NEW INTERNAL MIGRATION DESTINATION IN TURKEY ${ }^{(*)}$}

By

Ali T. Akarca ${ }^{(* *)}$

$\&$

Aysit Tansel $^{(* * *)}$

July 20, 2015

(*) An earlier version of this paper was presented at the $14^{\text {th }}$ International Conference of the Middle East Economic Association (MEEA), held in Hammamet, Tunisia, 23-25 March 2015. We benefited greatly from the comments we have received from the audience there. We are grateful to Metin Aytaç and Gürol İlhan from the Population and Migration Section of the Turkish Statistical Institute for meticulously gathering and providing us with the unpublished census data on characteristics of immigrant groups in Antalya and Muğla, to Aykut Mert Yakut, Halil Keskin, and Emre Demirezen, for assisting us in organizing the data, and to Gül İpek Tunç for directing us to some of the data sources.

(**) Department of Economics (mc 144), University of Illinois at Chicago, 601 S. Morgan Street, Chicago, Illinois 60607, USA. E-mail: akarca@uic.edu

(***) Department of Economics, Middle East Technical University, 06531 Ankara, Turkey, Institute for Study of Labor (IZA), P.O. Box 7240, D-53072 Bonn, Germany, and Economic Research Forum (ERF) Cairo, Egypt. E-mail: atansel@metu.edu.tr 


\begin{abstract}
Antalya and Muğla provinces located in southwestern Turkey have emerged as new magnets for internal migration in the country. Socio-economic, demographic and labor market characteristics of immigrants coming to these two provinces from various regions are studied to uncover the reasons fueling their moves. This is accomplished through an analysis of descriptive statistics, and an analysis of a gravity model estimated. Differences and similarities between immigrants coming to these two provinces and those going to other migrant magnets, between immigrants and natives in Antalya and Muğla, and among immigrants coming to the two provinces from various origins are noted. What distinguishes Antalya and Muğla from other migrant-drawing provinces is that they attract some retirees and university students as well and their immigrants participating in the labor force are attracted mainly by jobs created in the sectors related to tourism, either directly or indirectly, rather than industry. Immigrants from different origins exhibit different characteristics and tend to specialize in different types of jobs. However, as other migrant flows, those directed at Antalya and Muğla are affected by distance adversely and by unemployment differential, past migration and population size at origin, favorably.
\end{abstract}

Keywords: Internal migration, labor market, gravity model, Turkey, Antalya, Muğla.

JEL Classifications: J21, J61, R23. 


\section{Introduction}

During the last sixty-five years a massive internal migration has taken place in Turkey. As a consequence of this, the urbanization rate has increased from about 25 percent in 1950 to 42 percent in 1975, 65 percent in 2000 and 77 percent in 2012. Now over 40 percent of Turkish population resides in a province other than the one in which they were born. This figure was 28 percent in 2000, 17 percent in 1975, and only 12 percent in 1950. ${ }^{1}$ This population movement was essentially from the east, southeast and north towards the northwest, west and south, and from the less urbanized, less industrialized, and poorer regions of the country, to the more urbanized, more industrialized and richer regions. However, in recent years the southwest has emerged as a new major migrant destination.

During 1975-1980 and 1980-1985 periods, the provinces with the highest net migration rates (between 4 and 11 percent per five years) were Kocaeli, İstanbul and Bursa provinces in the northwest, surrounding the eastern half of the Marmara Sea, İzmir in the west, on the central Aegean coast, and Mersin (named İçel until 2002) in the south, along the eastern shores of the Mediterranean. These, together with Ankara, in central Anatolia, and Adana, in the south, on the eastern Mediterranean coast, had the highest in-migration also in absolute numbers. These seven provinces received almost half of all of the inter-provincial migration. In 1990, the urbanization rates of these provinces ranged between 61 and 91 percent, the share of industry in total employment, between 9 and 34 percent, and the part of real GDP attributable to industry, between 28 and 57 percent.

After 1985, Antalya and Tekirdağ, and after 1995, Muğla and Bilecik joined the list of provinces with net migration rates exceeding 4 percent per five years. In fact, for the period 19952000, Tekirdağ, Muğla, Antalya and Bilecik ranked first through fourth, ahead of İstanbul, Bursa, and İzmir, which remained on the list, and Kocaeli, and Mersin, which dropped out of it. ${ }^{2}$ Antalya ranked $5^{\text {th }}$, Tekirda $\breve{g} 10^{\text {th }}$, Muğla $11^{\text {th }}$, and Bilecik $52^{\text {nd }}$ among 81 provinces, in migrants received in absolute value. Their corresponding ranks were $15^{\text {th }}, 23^{\text {rd }}, 47^{\text {th }}$, and $50^{\text {th }}$ respectively, among 67 provinces in the period 1975-1980. In Figure 1, the net migration rates of the eleven provinces mentioned are contrasted for various periods. Table 1, reports various socio-economic and demographic characteristics of these provinces obtained from the last population census conducted in 2000. Tables 2 through 4 give an idea about the structures of their economies and how they have changed over time.

\footnotetext{
${ }^{1}$ Although place of birth data is available for five year intervals during 1950-2000, it is not for later years. Instead, place of birth registry has been reported since 2008, which is essentially the same as the place of birth. In this paper, for the years after 2008 , the former is reported as a close substitute of the latter.

${ }^{2}$ The net migration rate of Mersin dropped to 1 percent during 1995-2000, from 7 percent during 1985-1990. In the case of Kocaeli, the corresponding drop was even more dramatic, from almost 11 percent to zero. However the latter is caused mainly by the two earthquakes that hit the province in 1999 , and turned out to be a temporary phenomenon. Now people born outside of that province constitute more than two-thirds of the province's residents, which ranks second in the country in that regard.
} 
The jump in the net migration rates of Tekirdağ and Bilecik can be considered continuation of the old pattern, as both of these provinces are in the northwestern section of the country which has been a major magnet for those who leave their provinces. Both are heavily industrialized and urbanized. In 2000, about one fifth to one-fourth of their employment and about half of their real GDP originated in their industrial sectors. In the same year, almost two-thirds of their population was classified as urbanized. Migration flows to Antalya and Muğla, on the other hand, constitute a new path. These provinces are located in the southwest, outside the traditional migration destinations. They have relatively high per capita income levels but are not urbanized and their economies rely mostly on agriculture and services (especially hotel and restaurant services). In 2000, the urbanization rates of the two provinces were 54 and 38 percent, and ranked $42^{\text {nd }}$ and $77^{\text {th }}$ among the 81 provinces, respectively. ${ }^{3}$ The share of industrial sector in total employment was 5.5 percent for Antalya, and 6.0 percent for Muğla. These ranked $51^{\text {st }}$ and $47^{\text {th }}$ among the 81 provinces. In contrast, the shares of agriculture and services in total employment were 49.8 and 39.4 percent for Antalya, and 55.1 and 34.0 percent for Muğla. The proportion of real GDP attributable to agriculture, industry and services for the two provinces were 19.1, 8.4 and 64.0, respectively, for the former, and 18.5, 28.4 and 45.9 for the latter. What distinguishes these two provinces from the rest is the unusually large size of their tourism-related sectors and the phenomenal growth they have exhibited. For these two provinces, the share of hotel and restaurant services sector in total employment was more than three times the national average, and in real GDP, more than seven times. The growth of the sector's employment was more than double that of the country. The portion of hotel and restaurant services in 2000 real GDP was 22.3 and 19.5 percent for Antalya and Muğla, respectively. The corresponding figures for all other provinces were in the single digits, except for Nevşehir, which barely made it to a double digit level. Antalya and Muğla ranked very high (second and third in the nation) also in absolute value of this sector's output, surpassed only by İstanbul. During 19902000, the average annual growth rate of the sector's output was 6.2 percent in Antalya and 9.0 percent in Muğla. The same sector's employment grew at the rate of 8.3 percent in Antalya and 8.4 percent for Muğla. These growth rates in output and employment exceeded substantially those of other sectors and those of other provinces in that sector.

It should also be noted that, although a lot of immigrants arriving at Antalya and Muğla are from traditional, poor, agricultural and rural provinces, more than a third of them come from the seven provinces mentioned above which get the lion's share of internal migration. Thus it appears that these two provinces have emerged as new migrant destinations and exhibit characteristics quite different than other major migrant-drawing provinces. Now the urbanized, industrialized and wealthier regions of Turkey are not only sharing immigrants leaving the less-urbanized, agricultural, and poorer regions of the country with these two provinces, they in fact have begun to lose a part of their own populations to them.

The aim of this study is to examine socio-economic and demographic characteristics of migrants coming to Antalya and Muğla from various provinces, and their labor market status, to uncover the reasons fueling their moves. This will be accomplished through an analysis of

\footnotetext{
${ }^{3}$ With continued immigration over the next decade, the urbanization rates of Antalya and Muğla reached 71 and 44 percent by 2012, but these figures are still lower than the national average.
} 
descriptive statistics in the next section, and an analysis of a gravity model built and estimated in the section following that. Our analysis will be restricted to the 1995-2000 period because detailed data on internal migration is not yet available for the period after $2000 .{ }^{4}$ In the fourth section, our main findings will be summarized and conclusions will be presented.

\section{Characteristics of immigrants in Antalya and Muğla}

After drawing attention to the features distinguishing Antalya and Muğla in general from other migrant magnets, we now turn our attention to the characteristics of provinces which send migrants to the two provinces. We will also investigate whether the characteristics of the migrants differ from those of the natives and differ among themselves according to their origins.

Not to get lost in detail, we will focus on the top fifteen provinces from where migrants to southwest originate. These provinces, listed in Table 5 and marked in Figure 2, account for almost 60 percent of in-migration to Antalya and Muğla. Recognition of patterns will be enhanced if we divide the fifteen provinces into three groups: three distant ones in the western half of the country (Istanbul, Kocaeli, and Ankara), ten provinces surrounding Antalya and Muğla (İzmir, Aydın, Mersin, Adana, Hatay, Denizli, Afyon, Burdur, Isparta, and Konya), and two distant ones in the eastern Turkey (Diyarbakir and Van). Henceforth we will refer to them as the first, second and third groups. In Tables 5 through 8 , we shaded the rows for provinces in the first and third groups and placed the ones in the second group in between them to facilitate comparisons. Further partitioning of the second group into five coastal and five non-coastal provinces will be very helpful as well. In the unshaded parts of the mentioned tables, the coastal provinces are placed first, then the land-locked ones. The provinces in the first group which incorporates the two largest metropolitan areas and the coastal ones in the second group, especially Izmir which includes the third largest metropolitan area, constitute the most advanced parts of the country. The provinces in the east are among the least advanced. The rest of the provinces in the second group fall in between.

The map in Figure 2 and Table 5 give interesting clues as to what factors in general play a role in migration. The fact that three most populous provinces (İstanbul, Ankara and İzmir) generate the highest proportions of migrants to Antalya and Muğla (collectively more than a fourth) suggests that population size may be an important determinant which is consistent with the migration literature. That ten of the top fifteen migrant generating provinces are clustered around the migrants' destinations may be interpreted as distance being a key variable as well. Indeed, in most studies, the distance between the origin and the destination is treated as a proxy for the cost of moving, including the psychic costs of removal from loved ones, a familiar culture and environment, and costs of information acquisition, besides transportation costs.

\footnotetext{
${ }^{4}$ However, we can report that migration to Antalya and Muğla is continuing at about the same rate as just before 2000. Proportion of residents born outside Antalya which increased from 14 percent in 1985 and 23 percent in 1990 to 36 percent in 2000, reached 51 percent in 2013. In case of Muğla, the corresponding figures were 10 percent in 1985 , 15 percent in 1990, 27 percent in 2000 and 36 percent in 2013. The two provinces are now ranked $7^{\text {th }}$ and $12^{\text {th }}$ in the nation in that regard.
} 
Six of the fifteen provinces listed in Table 5 are also among the fifteen provinces with the highest unemployment rates in the country. Thus high unemployment appears as yet another important factor motivating migration to the southwest. Indeed according to the 2000 census, almost a third of those who migrated to Antalya and Muğla during 1995-2000 gave desire to find a job as the most important reason behind their move. If we add to that the non-working spouses and dependents of these people, we can safely tie majority of the migrants to the job factor.

Four of the six provinces with the highest unemployment rates (İstanbul, Ankara, Diyarbakır and Van) are far away from Antalya and Muğla, implying that a desire to find a job may outweigh the effect of distance. However there are other provinces with even higher unemployment rates and which are closer. Yet they do not send many migrants to the two provinces in question. Fourteen provinces lying between Syrian and Iraqi borders and a line drawn from the northwestern border of Mersin and Adana to the northeastern border of Van and Iran, together with İstanbul, Ankara and İzmir, capture all of the provinces with unemployment rates exceeding 10.5 percent in 2000 . Among them only four are distant, and among the top migrant originators, at the same time. Thus beside high unemployment, another factor must be at play. What differentiates the four provinces from the rest is the fact that they are among those with substantial past migration to Antalya and Muğla. Presence of friends, family and other contacts already at the destination, tends to lower costs of moving mentioned above and increases the probability of finding a job. These are referred to as "kinship" or "network" effects in the literature. So important these are in Turkey that there is a special Turkish word for them: hemşehrilik. It describes the solidarity between hemşehris, the people who are originally from the same town or region. Fourteen of the fifteen provinces listed in Table 5 are among the twenty-three provinces (out of 79) with the highest proportions of hemşehris in Antalya and Muğla. So this factor is important as well. In the case of Kocaeli, the only one of the fifteen provinces missing from the list of top twenty-three hemşehris, two major earthquakes which hit it in 1999 was the main reason for high out-migration.

A comparison of Tables 1-2 and 5-8, reveals that migrants are different than the natives in Antalya and Muğla. Migrants are younger, better educated, and more male than the natives. Their labor force participation, unemployment rate, and proportion working in non-agricultural jobs are substantially higher. Among them, the proportion of those employed in construction, and hotel and services sectors are about twice that of averages for the two provinces. Not only migrants differ from the natives, but they also differ from each other, depending on their origins and destinations. Those in Muğla are more educated, more male-dominated and slightly older than those in Antalya. The age and gender related differences mentioned apply regardless of the origins of immigrants. Compared to those coming from nearby provinces, migrants from provinces in the first group and Izmir in the second group are older and more educated, but no pattern is discernible in regards to gender. On the other hand, the migrants originating from eastern provinces are substantially younger, less educated and more male-dominated than the rest.

Labor Force participation rate among immigrants is higher in Muğla than in Antalya: 71 vs 63 percent. These rates are slightly higher than the corresponding provincial rates. The participation gap between the two provinces exists for immigrants from all origins. The rate is much lower for those coming from group 1 provinces and higher among those coming from group 3 provinces. Of 
those not participating in labor force in Antalya, 30 percent are students, 14 percent are retirees and 49 percent are housewives (or 11, 5 and 18 percent of all immigrants in the province, respectively). Similar figures for Muğla are 38, 14, and 40 percent of those not in the labor force, (or 11, 4, and 11 percent of all immigrants in the province, respectively). Since the bulk of the housewives are spouses of the men in the labor force, many of them should be considered as involved in job-seeking as well, but indirectly. Proportion of immigrant housewives not in the labor force is higher in Muğla than in Antalya, and among those originating from eastern provinces than the rest.

Migrant students include those attending primary, secondary and higher educational institutions but probably almost all of them are university students. Establishment of Akdeniz University in 1982 in Antalya and Muğla Sıtkı Koçman University in 1992 in Muğla, are behind this migration. ${ }^{5}$ Understandably, the students from provinces in close proximity of Antalya and Muğla make up a much larger percentage of those not participating in the labor force.

It appears that Antalya and Muğla attract retirees as well. The pleasant climates, nature and coasts of these two provinces play a key role in this. The ratio of retirees to those not in labor force is highest among immigrants from Istanbul and Ankara, and lowest among immigrants from Diyarbakır and Van. The latter two provinces have much harsher climates than Ankara and Istanbul but are much poorer. Thus bad climate, unless accompanied by some affluence at the origin, appears to be not sufficient for retirement-related migration. ${ }^{6}$ The ratio of retirees to those not in labor force is substantially lower for the coastal provinces in the second group than non-coastal ones. Obviously, benefits of moving for retirement is much smaller in the former which have similar climates and their own seaside resorts.

The main sectors in which the immigrants are employed are given in Table 8. Agricultural, and service-related jobs appear to attract migrants especially, followed by construction and trade related jobs. Manufacturing employs few migrants but is included in the table to draw attention to that fact. Among migrants from different origins, a tendency to specialize is observed. Those originating from coastal provinces near Antalya and Muğla, especially those to the east, concentrate on restaurant and hotel jobs. Migrants from non-coastal provinces bordering the two provinces on the other hand work predominantly in agriculture. ${ }^{7}$ Overwhelming portions of immigrants from distant eastern provinces take the construction jobs. Immigrants from provinces in the first group and Izmir from the second group seem to be drawn to wholesale and retail trade and various servicerelated jobs outside hotels and restaurants. ${ }^{8}$

\footnotetext{
${ }^{5}$ See Işık (2008) for a discussion of how education-related migration is gaining importance in Turkey, following establishment of a number of universities at various locations.

${ }^{6}$ Indeed, Erjem (2009) reports that in a survey of migrants to Mersin, a province on the Mediterranean coast bordering Antalya, only two percent mentioned the more favorable climate of the province as a motivating factor behind their move. More than 55 percent cited better job opportunities and about 30 percent, their relatives who were already living in Mersin.

${ }^{7}$ Interestingly, the portion of immigrants from Istanbul, working in agriculture in Muğla is quite large. Since Istanbul does not have much of a rural population, these must be people who migrated to Istanbul in the past from villages of other provinces relocating once again.

${ }^{8}$ The portion of those from Kocaeli working in service jobs in Muğla is unusually high. A large number of government employees who were transferred between the two provinces, probably due to the earthquakes in 1999, account for this.
} 
The patterns described above depict an interesting dynamic at play. As a result of rising affluence, more of the older and educated people in metropolitan areas in colder areas of the country began retiring in resort towns of Antalya and Muğla. After major universities are opened in Antalya and Muğla, students began arriving also, especially from provinces nearby. Most importantly, the two provinces emerged as major vacation spots for domestic and foreign tourists. More hotels, vacation homes and restaurants are being built to serve the ever increasing number of tourists, more dormitories and university buildings are being built to accommodate expanding student bodies, and more housing is being constructed to accommodate the retirees. Younger and less-educated migrants from the east come to work at these constructions. Immigrants from nearby coastal provinces come mainly to staff the hotels and restaurants. Immigrants from nearby non-coastal provinces on the other hand come to fill the agricultural jobs vacated by the natives who leave rural areas to take betterpaying hotel and restaurant jobs. Some of the latter, also fill the new agricultural jobs created as a consequence of a greater demand for food. Increase in the number of tourists, retirees and students cause a rise in demand for wholesale and retail trade, and health, entertainment, personal and governmental services. Migrants coming mainly from metropolitan areas in the West, fill the newly created jobs in these sectors. The new jobs created in agriculture, and service sectors however should be tied to tourism as well. The Leontief inverse obtained from the 2002 Turkish input-output table shows that a Turkish lira spent in a hotel or restaurant generates another lira's worth of indirect production in other sectors. For example it causes a 0.18 lira worth of production increase in agriculture, and 0.09 liras worth in wholesale and retail trade. A lira spent on construction of a hotel generates 0.09 lira of increase in the output of wholesale and retail trade.

\section{A gravity model for migration to Antalya and Muğla}

In the previous section we showed that migration to Antalya and Muğla is partially education and retirement related but is mainly to find a job. We suggested also that, whatever is the reason for migration, a large population at origin, a short distance between origin and destination, and a large number people from the origin already living at the destination, all stimulate migration from the origin to the destination. Although we found that immigrants from different regions are attracted to different kinds of jobs, we also noticed that, what instigates the job search in the first place may be the large unemployment differential between origin and destination. In this section, we will measure relative influences of these variables and test their significance formally. For this purpose we will employ a deviant of the so called gravity model.

The gravity model is very popular with researchers of migration in other countries, as it fits their data remarkably well. Major studies which discuss and/or apply this model include Dhar (1984), Muesser (1989), Greenwood (1997), Lucas (1997), Adrienko and Guriev (2004), Fan (2005), Phan and Coxhead (2010), Etzo (2011), Aldashev and Dietz (2012), and Buena (2012). Although there are many studies on internal migration in Turkey, for example, Munro (1974), Gedik (1996), Tunalı (1996), Pazarlığlu (1997), Gündüz and Yetim (1997), İçduygu and Ünalan (1998), Gezici and Keskin (2005), Kocaman (2008), and Filiztekin and Gökhan (2008), only the last one employed

the gravity model. None of them focused specifically on the migration flows to Antalya and Muğla, 
and they all treated migration flows to different destinations as if they are similar. We hope to gain more insight by studying the flows to the two provinces in question separately.

In view of a number of good surveys on the migration literature and the gravity model (for example, by Anderson, 2011, Etzo, 2008, and Greenwood and Hunt, 2003), we will not provide here yet another survey. However we will briefly explain what it involves. According to the basic gravity model, the flow of migrants between two locations is a function of the population of the sending location, its unemployment (or wage) rate relative to that of the receiving location and, the distance and previous migration between the two locations. It is assumed that the number of people moving away from a location is likely to be higher if its population is larger. Immigration is seen as an economic activity with its costs and benefits over time. Benefits are assumed to be higher for those moving from a high unemployment (low wage) area to a low unemployment (high wage) area. The current unemployment rate or earnings are taken as proxies for future employment possibilities and earnings. The distance between the origin and the destination is treated as a proxy for the cost of the move whatever the reason behind it. As we explained above, the latter captures more than just transportation costs. The presence of friends, family and other contacts already at the destination, the hemşehris, as a result of past migration, tends to lower costs and increase the probability of finding a job at the destination.

In the basic gravity model, it is assumed that the influences of population, distance, past immigration and unemployment differentials would be the same for all migration flows. We will include in our model all of these variables but we will fit separate equations for Antalya and Muğla and allow the parameter values to differ between the two equations. Typically, in empirical applications, in addition to the variables mentioned, other pull and push factors are also considered. We did as well. However, all of the additional variables tried, except one, provided unsatisfactory results. The exceptional variable was the one representing the intensity of the damage caused by the two earthquakes which devastated nine provinces in $1999 .{ }^{9}$ Loss of their businesses and/or homes may have hastened the decisions of those contemplating migrating, and may have triggered a desire to relocate among those who became fearful of similar disasters in the future. Also, many who became homeless were evacuated to hotels in Antalya and Muğla which are largely unoccupied during winter months. We have added a variable to the basic model to capture the earthquake factor.

Other factors we considered include the age distribution (median age), level of education (mean years of schooling), rate of urbanization, climate (average temperatures prevailing during the coldest and warmest months), all at the origin, relative to that at the destination, and the size of the originating province (its radius computed under the assumption that the province has a circular shape). However, none of these made a statistically significant contribution. The median age was considered because young migrants can expect a longer stream of wage differentials and stand to gain more from a move. The information acquisition and adjustment to a new environment should be easier and cheaper for the educated people and consequently would lead to higher emigration from provinces with higher mean years of schooling. That was the motivation behind trying the latter variable. Unfortunately, with macro data it was not possible to measure effects of these

\footnotetext{
${ }^{9}$ The nine provinces are the following: Bolu, Bursa, Düzce, Eskişehir, İstanbul, Kocaeli, Sakarya, Zonguldak and Yalova.
} 
variables separately because they are correlated with each other and with the unemployment variable already in the equations. Where unemployment rate is high, usually the median age and the education level are low. Urbanization level was considered because the extra urban amenities, such as health care and educational opportunities, gained by people moving from less urbanized areas are likely to be more. The idea behind the use of radius is that smaller localities are likely to have larger outmigration because it takes a shorter move to get out of the province than in larger provinces. Antalya and Muğla have very pleasant climates, which attract many tourists, domestic and foreign. The temperature variables were considered to check whether some of the permanent moves to this area are motivated by weather-related factors.

The final model we arrived at has the following form:

$$
\begin{aligned}
& \ln \mathrm{M}_{\mathrm{ij}}=\mathrm{a}_{\mathrm{j}}+\mathrm{b}_{\mathrm{j}} \ln \mathrm{P}_{\mathrm{j}}+\mathrm{c}_{\mathrm{j}} \ln \mathrm{D}_{\mathrm{ij}}+\mathrm{f}_{\mathrm{j}} \ln \left(\mathrm{U}_{\mathrm{i}} / \mathrm{U}_{\mathrm{j}}\right)+\mathrm{g}_{\mathrm{j}} \ln \mathrm{H}_{\mathrm{ij}}+\mathrm{n}_{\mathrm{j}} \ln \mathrm{Q}_{\mathrm{i}}+\mathrm{e}_{\mathrm{ij}} \quad \mathrm{i}=1,2,3, \ldots, 79 \\
& \mathrm{j}=80 \text { and } 81
\end{aligned}
$$

where

$\mathrm{M}_{\mathrm{ij}}$ : number of people who migrated from province $\mathrm{i}$ to province $\mathrm{j}$, between 1995 and 2000,

$\mathrm{P}_{\mathrm{i}}$ : resident population of province $\mathrm{i}$ in 1995 ,

$\mathrm{D}_{\mathrm{ij}}$ : highway distance (in kilometers) between the capital cities of provinces $\mathrm{i}$ and $\mathrm{j}$,

$\mathrm{U}_{\mathrm{i}}$ : unemployment rate in province $\mathrm{i}$,

$\mathrm{H}_{\mathrm{ij}}$ : number of people residing in province $\mathrm{j}$ in 1995 who were born in province $\mathrm{i}$,

$\mathrm{Q}_{\mathrm{i}}$ : $\quad$ number of residences and businesses in province $\mathrm{i}$ which suffered heavy damage in 1999 earthquakes,

$e_{i j}$ : the disturbance term for province $i$ in the equation for $j$,

and $a_{j}, b_{j}, c_{j}, f_{j}, g_{j}$, and $n_{j}(j=80,81)$ are parameters to be estimated. $j$ is equal to 80 for Antalya and 81 for Muğla. All variables are measured in logarithms, as it is typically done in applications of the gravity model.

The above equations are first estimated using Ordinary Least Squares (OLS) method, results of which are presented in the first two columns of Table 9. All of the parameters are statistically significant and the R-square values for the two equations are 0.93 and 0.87 . So the gravity model fits the data relatively well. However, large differences exist between the two equations in case of some parameter estimates, which are hard to explain. Also, some outliers are indicated. These may be caused by factors specific to particular origins which are missed. To make sure that such outliers did not contaminate our results, we estimated our equations also with robust regression procedure introduced by Rousseeuw (1984) and developed further by Rousseeuw and Van Driessen (2000) and 
Zaman et al. (2001). The last two columns of table 9 present those. Indeed, the procedure identifies nine outliers for Antalya equation and two for Muğla, which are listed in the notes of the table. ${ }^{10}$ When these are taken into account, cross-equation differences between the parameter values narrows to sensible levels and R-square values increase. We will base our analysis on the robust regressions which are more reliable, given the circumstances.

Because the variables in the equations are in logarithms, the parameters can be interpreted as elasticities. According to the estimation results, a percentage increase in the population of a province is expected to result in 0.52 percent more migration to Antalya and 0.60 percent more to Muğla. One percent increase in the distance of a province to the two provinces in question, on the other hand, causes 0.63 and 0.41 percent drop, respectively, in the number of migrants. A percent increase in the unemployment rate of a province (relative to that prevailing at the destination), leads to a 0.45 and 0.33 percent increase in the migration flows, respectively. Migration from one location to another leads to more migration in the future. Existence of hemşehris from a particular province appear to have the same effect on the migration from that province both in in Antalya and Muğla. One percent increase in the number of people from an origin living in southwestern Turkey generates $0.38-0.39$ percent more migration from that province. Likewise, it appears that the 1999 earthquakes have increased the migration from the provinces impacted to Antalya and Muğla in similar ways. Each percentage increase in the number of residences and businesses which suffered heavy quake damage in a province, translated into a little less than 0.02 percent increase in migration to Antalya and Muğla. Even though this is quite small, not including this variable in the migration equations would have biased the other results.

\section{Summary and conclusions}

Lately Antalya and Muğla provinces lying along the coast where the Aegean and the Mediterranean seas meet, have emerged as new migrant magnets. These receive substantial numbers of immigrants not only from the less developed areas of the country but also from the traditional migrant-drawing provinces. The two provinces differ from other migrant magnets in some key respects. First of all, they are not highly urbanized. Therefore, the migration towards them cannot be attributed to the availability of urban amenities. Also, unlike traditional migrant destinations, their industrial sectors are very small, and employ only a fraction of immigrants. What draws migrants to these provinces is essentially jobs created in the sectors related to tourism, either directly (such as in hotels and restaurants) or indirectly (such as in agriculture, trade and other services). The pleasant climates of the two provinces attract, not only tourists, but also some retirees from rich provinces. New universities opened in the two provinces bring in students as migrants as well. The last two groups in turn create jobs for other migrants, directly or indirectly.

11 percent of immigrants who arrived in Antalya, during 1995-2000, came to study, 5 percent to retire, 18 percent as housewives, and 63 percent to join the labor force. Corresponding figures for

\footnotetext{
${ }^{10}$ In case of these provinces other pull and/or push factors must be at play which need to be studied further but this is beyond the aim of the current study.
} 
Muğla are 11, 4, 11, and 71 percent. Thus migration to these destinations are partly education and retirement related, but mainly motivated by finding a job. Immigrants arriving at these two provinces from different regions exhibit different demographic and socio-economic characteristics, and a tendency to work at different sectors of the economy. Those coming from less developed eastern provinces tend to be young, less-educated and work predominantly in the construction sector. They build the hotels, restaurants, and vacation homes for the domestic and foreign tourists, and homes for the older and better-educated retirees coming from the more developed metropolitan areas, and dormitories and school buildings for the students coming mostly from the provinces surrounding Antalya and Muğla. Immigrants from nearby coastal provinces staff the hotels and restaurants, and those from nearby non-coastal provinces replace the natives who leave their agricultural jobs for better paying ones in hotels and restaurants. Immigrants from other provinces but mainly from the metropolitan areas take the trade related and other kinds of service jobs created as a result of increased activity in tourism.

On the other hand, in some respects, migration to Antalya and Muğla is similar to migration to traditional destinations Our strong empirical findings that desire to find a job or a better job is the main motivation behind migration, that immigrants from earlier eras living at a destination encourages further migration, that distance is a strong hindrance to migration, and that migration from a location is positively related to its population, are similar to findings of other studies on migration to other destinations.

\section{References}

Aldashev, A. and Dietz, B. 2012. "Economic and spatial determinants of interregional migration in Kazakhstan,” IZA discussion paper No. 6289.

Anderson, J. E. 2011. “The gravity model,” The Annual Review of Economics, Vol. 3, pp.133-160.

Andrienko, Y. and Guriev, S. 2004. "Determinants of inter-regional mobility in Russia," Economics of Transition, Vol. 12, pp. 1-27.

Buena, D. 2012. "Modern gravity models of internal migration: The case of Romania," Theoretical and Applied Economics, Vol. 19, pp. 127-144.

Dhar, S. 1984. "Inter-state and within-state migration in India," in Contractual Arrangements, Employment and Wages in Rural Labor Markets in Asia, Binswanger, H. P. and Rosenzweig, M. R. (eds), Economic Growth Center, Yale University, pp. 281-304.

Erjem, Y. 2009. Mersin'de Göç Kentleşme ve Sosyal Problemler (Migration, Urbanization and Social Problems in Mersin), Mersin: Office of the Governor Publications, Social Research Series Number 1. 
Etzo, I. 2011. "The determinants of recent interregional migration flows in Italy: A panel data analysis," Journal of Regional Science, Vol. 51, pp. 948-966.

Etzo, I. 2008. “Internal migration: A review of the literature,” MPRA Working Paper No. 8783.

Fan, C. C. 2005. "Modeling interprovincial migration in China 1985-2000," Eurasian Geography and Economics, Vol. 46, pp. 165-184.

Filiztekin, A. and Gökhan, A. 2008. "The determinants of internal migration in Turkey," paper presented at International Conference on Policy Modelling (EcoMod2008), Berlin, Germany, 2-4 July 2008.

Gedik, A. 1996. "Internal migration in Turkey, 1965-85: Test of some conflicting findings in the literature," Working Paper in Demography No. 66, Austrian National University, Canberra, Australia.

Gezici, F. and Keskin, B. 2005. "Interactions between regional inequalities and internal migration in Turkey," paper presented at the 45th Congress of the European Regional Science Association: Land Use and Water Management in a Sustainable Network Society, Amsterdam, 23-27 August 2005.

Greenwood, M. J. and Hunt, G. L. 2003. "The early history of migration research," International Regional Science Review, Vol. 26, pp. 3-37.

Greenwood, M. J. 1997. "Internal migration in developed countries," in Rosenzweig, M. R. and Stark, O. (eds.), Handbook of Population and Family Economics, Vol. 1B, Elsevier, Amsterdam, pp. 647-720.

Gündüz, M. and Yetim, N. 1997. "Terör ve göç," (Terrorism and migration) in Toplum ve Göç-II. Ulusal Sosyoloji Kongresi (November 20-22, 1996, Mersin) Bildiriler Kitabl, SIS Pub. Number 2046, Ankara, SIS, pp. 109-118.

İçduygu, A. and Ünalan, T. 1998. "Türkiye'de iç göç: Sorunsal alanları ve araştırma yöntemleri," (Internal migration in Turkey: Its problem areas and research methods) in Türkiye'de Iç Göç, Sorunsal Alanları ve Araştırma Yöntemleri Konferansı (June 6-8, 1998, Bolu-Gerede) Bildiriler Kitabı. İstanbul: Türkiye Ekonomik ve Toplumsal Tarih Vakfı, pp. 38-55.

Işık, Ş. 2008. "Türkiye'de Eğitim Amaçlı Göçler” (Educational migration in Turkey), Coğrafi Bilimler Dergisi, Vol. 7, pp. 27-37.

Kocaman, T. 2008. Türkiye'de Iç Göçler ve Göç Edenlerin Nitelikleri: 1965-2000 (Internal migration in Turkey and the characteristics of those who migrate: 1965-2000), Ankara: State Planning Organization, Prime Ministry, the Republic of Turkey. 
Lucas, R. E. B. 1997. "Internal migration in developing countries," in Rosenzweig, M. R. and Stark, O. (eds), Handbook of Population and Family Economics, Volume 1B, Elsevier, Amsterdam, pp. 721-798.

Mueser, P. 1989. "The spatial structure of migration: an analysis of flows between states in the USA over three decades," Regional Studies, Vol. 23, pp. 185-200.

Munro, J. 1974. “Migration in Turkey,” Economic Development and Cultural Change, Vol. 22, pp. 634-53.

Pazarlığlu, M. V. 1997. “1980-1990 döneminde Türkiye’de iç göç üzerine ekonometrik model çalışması," (An Econometric model study on internal migration in Turkey for the period 1980-1990) Çukurova University V. National Econometrics and Statistics Symposium, Adana.

Phan, D. and Coxhead, I. 2010. "Inter-provincial migration and inequality during Vietnam's transition," Journal of Development Economics, Vol. 91, pp.100-112.

Rousseeuw, P.J. 1984. "Least Median of Squares Regression," Journal of the American Statistical Association, Vol. 79, pp. 871-880.

Rousseeuw, P.J. and Van Driessen, K. 2000. "An Algorithm for Positive-Breakdown Regression Based on Concentration Steps," in W. Gaul, O. Opitz, and M. Schader (eds), Data Analysis: Scientific Modeling and Practical Application, New York: Springer-Verlag, pp. 335-346.

SAS. 2008. SAS/STAT 9.2 User's Guide. Cary, North Carolina: SAS Institute Inc.

Tunal1, İ. 1996. "Migration and remigration of male household heads in Turkey, 1963-1973," Economic Development and Cultural Change, Vol. 45, pp. 56-67.

Zaman, A., Rousseeuw, P.J. and Orhan, M. 2001. "Econometric Applications of High-Breakdown Robust Regression Techniques,” Econometrics Letters, Vol. 71, pp. 1-8. 
Figure 1

Net migration rates for key migrant magnets (per thousand)

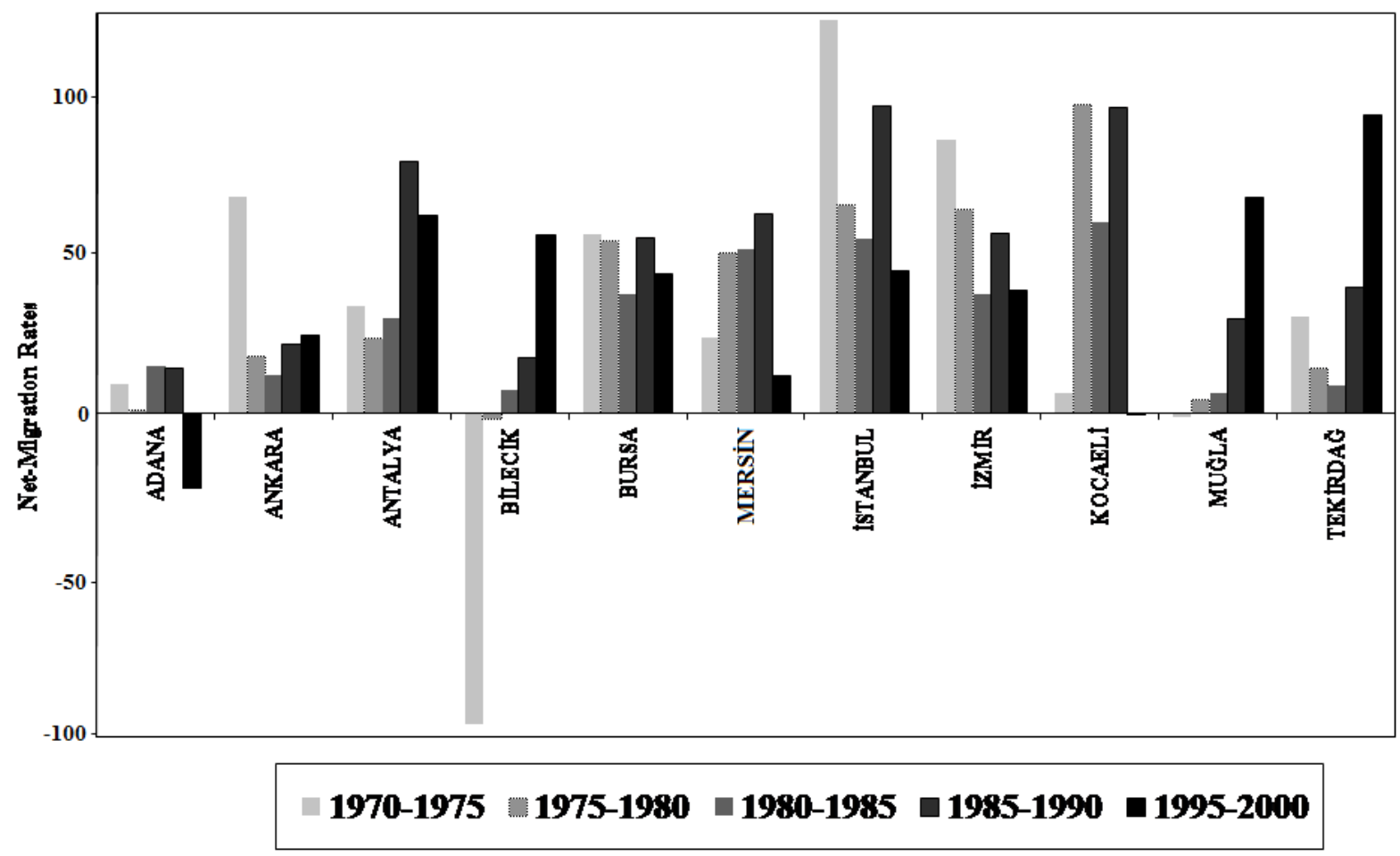

Source:

Turkish Statistical Institute (Prime Ministry, the Republic of Turkey). 
Figure 2: Origins of Immigrants in Antalya+Muğla (1995-2000)

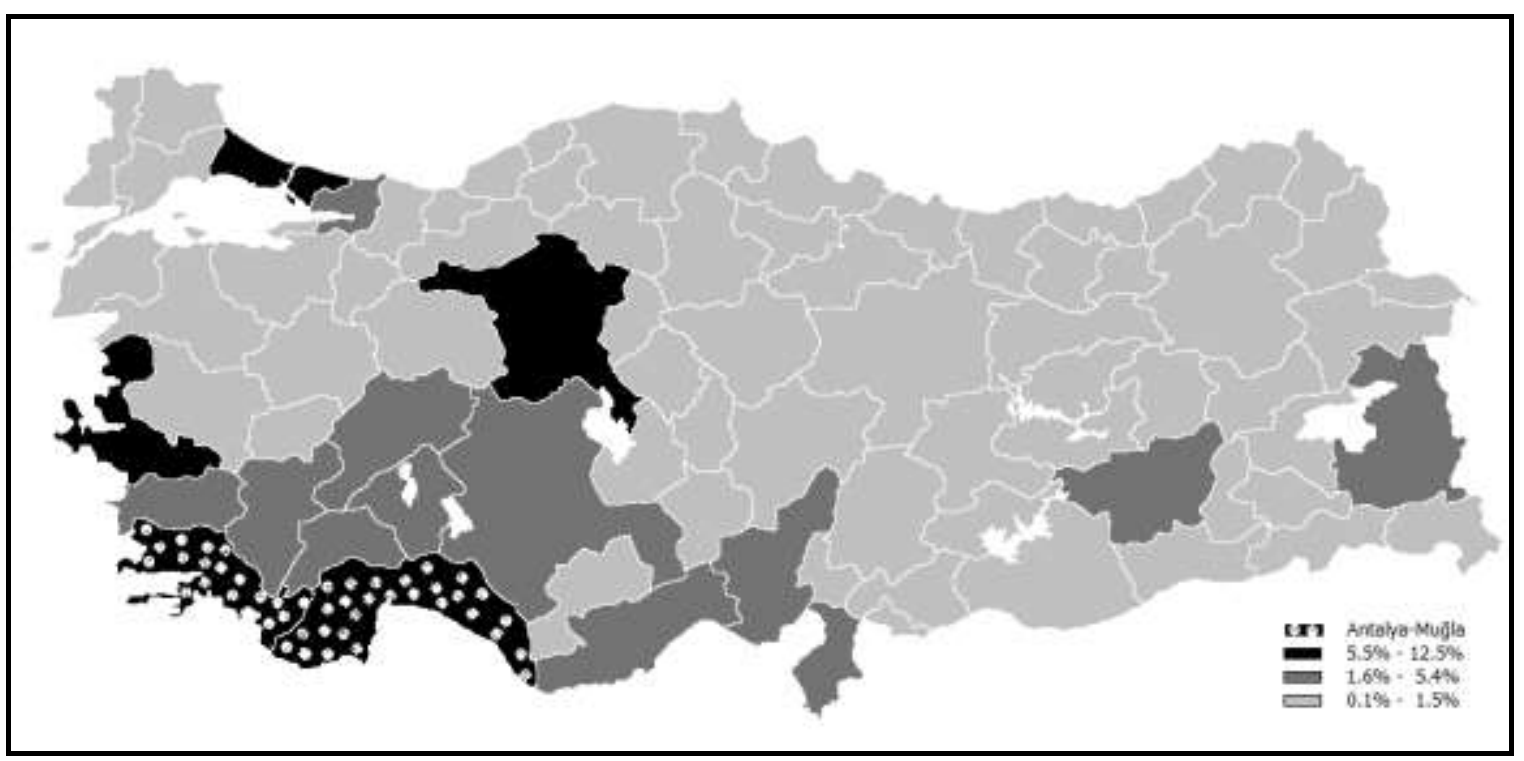

Notes:

Migration from the province to Antalya+ Muğla between 1995 and 2000, in proportion to total inmigration to the latter during the same period.

Source:

Turkish Statistical Institute (Prime Ministry, the Republic of Turkey). 
Table 1

Socio-Economic Characteristics of Key Migrant Magnets

\begin{tabular}{|c|c|c|c|c|c|c|c|}
\hline & $\begin{array}{c}\text { Urbanization } \\
\text { Rate (\%) } \\
(2000) \\
\end{array}$ & $\begin{array}{c}\text { Median } \\
\text { Age (years) } \\
\\
(2000) \\
\end{array}$ & $\begin{array}{c}\begin{array}{c}\text { Mean Years } \\
\text { of Schooling }\end{array} \\
(2000) \\
\end{array}$ & $\begin{array}{c}\text { Net } \\
\text { Migration } \\
\text { Rate (\%) } \\
(1995-2000) \\
\end{array}$ & $\begin{array}{c}\text { Per Capita } \\
\text { Real GDP } \\
\left({ }^{6} 000 \mathrm{TL}\right) \\
(2000) \\
\end{array}$ & $\begin{array}{c}\begin{array}{c}\text { Not in Labor } \\
\text { Force }(\%)\end{array} \\
(2000) \\
\end{array}$ & $\begin{array}{c}\text { Unemployment } \\
\text { Rate (\%) } \\
(2000)\end{array}$ \\
\hline Turkey & 64.9 & 24.8 & 5.4 & - & 1760.9 & 44.8 & 8.9 \\
\hline Adana & 75.6 & 23.5 & 5.3 & -2.4 & 1933.4 & 51.5 & 14.3 \\
\hline Ankara & 88.3 & 26.8 & 6.8 & 2.6 & 2397.5 & 51.8 & 11.0 \\
\hline Antalya & 54.5 & 28.1 & 6.1 & 6.4 & 1723.4 & 39.6 & 7.9 \\
\hline Bilecik & 64.0 & 28.9 & 5.7 & 5.8 & 2959.5 & 43.5 & 4.7 \\
\hline Bursa & 76.8 & 28.0 & 5.7 & 4.5 & 2401.1 & 46.3 & 9.3 \\
\hline Mersin & 60.5 & 24.6 & 5.4 & 1.2 & 1861.9 & 45.1 & 10.2 \\
\hline İstanbul & 90.7 & 26.3 & 6.2 & 4.6 & 2645.3 & 49.8 & 12.7 \\
\hline İzamir & 81.1 & 28.8 & 6.1 & 4.0 & 2680.1 & 47.8 & 10.8 \\
\hline Kocaeli & 59.9 & 25.7 & 5.8 & 0.0 & 4376.8 & 41.9 & 8.3 \\
\hline Muğla & 37.5 & 30.0 & 6.0 & 7.0 & 2663.2 & 29.9 & 4.3 \\
\hline Tekirdağ & 63.4 & 28.6 & 5.8 & 9.7 & 2535.9 & 36.8 & 6.3 \\
\hline
\end{tabular}

Notes:

In the computation of mean years of schooling for each province, $15,11,8$, and 5 years of schooling are attributed, respectively, to university, high school, middle school, and primary school graduates in the province. Two years-worth of schooling is attributed to those who are literate but not a graduate of any school. Children under age six are omitted in computing the mean. Per capita real GDP is in 1987 TL.

Source:

Authors' computations using data provided by the Turkish Statistical Institute (Prime Ministry, the Republic of Turkey). 
Table 2

Employment in Key Migrant Magnets: Sectoral Breakdown and Annual Growth Rates

\begin{tabular}{|c|c|c|c|c|c|c|c|c|c|c|c|c|c|c|c|c|}
\hline & \multicolumn{10}{|c|}{ Share $(\%)$} & \multicolumn{6}{|c|}{ Growth Rate (\%) } \\
\hline & \multicolumn{2}{|c|}{ Agriculture } & \multicolumn{2}{|c|}{ Industry } & \multicolumn{2}{|c|}{ Construction } & \multicolumn{2}{|c|}{ All Services } & \multicolumn{2}{|c|}{$\begin{array}{l}\text { Hotel and } \\
\text { Restaurant } \\
\text { Services }\end{array}$} & \multirow{2}{*}{\begin{tabular}{|c|} 
Agriculture \\
$1990-2000$
\end{tabular}} & \multirow{2}{*}{\begin{tabular}{|l|} 
Industry \\
$1990-2000$
\end{tabular}} & \multirow{2}{*}{\begin{tabular}{|c|} 
Construction \\
$1990-2000$ \\
\end{tabular}} & \multirow{2}{*}{\begin{tabular}{|c} 
All \\
Services
\end{tabular}} & \multirow{2}{*}{\begin{tabular}{|c|}
$\begin{array}{c}\text { Hotel and } \\
\text { Restaurant } \\
\text { Services }\end{array}$ \\
$1990-2000$ \\
\end{tabular}} & \multirow{2}{*}{\begin{tabular}{|c|} 
Total \\
$1990-2000$
\end{tabular}} \\
\hline & 1990 & 2000 & 1990 & 2000 & 1990 & 2000 & 1990 & 2000 & 1990 & 2000 & & & & & & \\
\hline Turkey & 54.0 & 48.4 & 12.9 & 13.4 & 5.1 & 4.6 & 28.0 & 33.6 & 2.0 & 2.6 & 0.0 & 1.5 & 0.1 & 3.0 & 3.7 & 1.1 \\
\hline Adana & 49.8 & 43.1 & 14.8 & 14.4 & 5.3 & 4.9 & 30.0 & 37.6 & 2.1 & 2.6 & -3.0 & -1.9 & -2.6 & 0.6 & 0.4 & -1.6 \\
\hline Ankara & 18.2 & 16.3 & 14.3 & 13.4 & 7.2 & 6.4 & 60.2 & 63.9 & 2.7 & 3.2 & 1.1 & 1.6 & 1.0 & 2.9 & 4.0 & 2.3 \\
\hline Antalya & 57.4 & 49.8 & 6.4 & 5.5 & 7.1 & 5.3 & 29.1 & 39.4 & 6.1 & 9.8 & 1.8 & 1.7 & 0.3 & 6.4 & 8.3 & 3.2 \\
\hline Bilecik & 55.9 & 46.7 & 16.1 & 19.4 & 3.5 & 3.4 & 24.5 & 30.5 & 1.3 & 1.9 & -1.7 & 1.9 & -0.2 & 2.2 & 3.9 & 0.0 \\
\hline Bursa & 40.5 & 33.6 & 25.8 & 28.2 & 6.2 & 5.0 & 27.6 & 33.3 & 2.7 & 3.2 & 0.4 & 3.2 & 0.0 & 4.3 & 3.9 & 2.3 \\
\hline Mersin & 55.4 & 57.7 & 8.9 & 7.9 & 6.6 & 4.5 & 29.1 & 29.9 & 2.2 & 2.2 & 2.5 & 0.9 & -1.9 & 2.3 & 1.8 & 2.1 \\
\hline İstanbul & 5.2 & 8.1 & 34.2 & 32.2 & 9.0 & 6.2 & 51.6 & 53.4 & 4.2 & 4.5 & 8.0 & 2.7 & -0.4 & 3.7 & 4.1 & 3.3 \\
\hline İzmir & 32.6 & 28.6 & 20.5 & 20.6 & 6.4 & 5.3 & 40.4 & 45.5 & 3.1 & 3.6 & 0.5 & 1.9 & -0.1 & 3.0 & 3.2 & 1.8 \\
\hline Kocaeli & 33.0 & 39.1 & 24.1 & 20.3 & 8.5 & 8.3 & 34.4 & 32.3 & 2.3 & 2.3 & 5.7 & 2.1 & 3.7 & 3.2 & 4.0 & 3.9 \\
\hline Muğla & 61.1 & 55.1 & 7.8 & 6.0 & 7.3 & 4.9 & 23.9 & 34.0 & 4.5 & 7.9 & 1.5 & -0.1 & -1.5 & 6.2 & 8.4 & 2.5 \\
\hline Tekirdağ & 47.5 & 38.8 & 16.9 & 26.2 & 6.6 & 4.1 & 29.0 & 30.9 & 2.1 & 2.4 & 0.4 & 7.0 & -2.4 & 3.0 & 4.2 & 2.4 \\
\hline
\end{tabular}

Source:

Authors' computations using data provided by the Turkish Statistical Institute (Prime Ministry, the Republic of Turkey). 
Table 3

Real GDP in Key Migrant Magnets: Sectoral Breakdown (\%)

\begin{tabular}{|c|c|c|c|c|c|c|c|c|c|c|c|c|c|c|c|}
\hline & \multicolumn{3}{|c|}{ Agriculture } & \multicolumn{3}{|c|}{ Industry } & \multicolumn{3}{|c|}{ Construction } & \multicolumn{3}{|c|}{ All Services } & \multicolumn{3}{|c|}{$\begin{array}{c}\text { Hotel and } \\
\text { Restaurant Services }\end{array}$} \\
\hline & 1990 & 1995 & 2000 & 1990 & 1995 & 2000 & 1990 & 1995 & 2000 & 1990 & 1995 & 2000 & 1990 & 1995 & 2000 \\
\hline Turkey & 25.7 & 25.8 & 24.9 & 17.2 & 18.9 & 20.6 & 5.3 & 5.4 & 5.0 & 37.5 & 41.7 & 46.6 & 2.0 & 2.3 & 2.6 \\
\hline Adana & 18.9 & 20.2 & 14.8 & 28.5 & 31.1 & 32.4 & 4.8 & 4.1 & 2.8 & 43.9 & 41.3 & 44.1 & 1.6 & 1.5 & 1.7 \\
\hline Bilecik & 18.2 & 14.0 & 13.6 & 45.2 & 52.8 & 51.4 & 3.8 & 3.6 & 4.1 & 28.0 & 25.8 & 26.4 & 0.7 & 0.5 & 0.6 \\
\hline Bursa & 17.3 & 13.4 & 9.7 & 36.0 & 40.0 & 42.1 & 6.4 & 6.2 & 4.2 & 34.2 & 35.5 & 36.9 & 2.2 & 2.4 & 2.4 \\
\hline Mersin & 20.1 & 15.8 & 20.9 & 27.8 & 27.9 & 23.6 & 6.2 & 5.7 & 2.8 & 40.1 & 44.2 & 45.7 & 3.1 & 3.4 & 3.5 \\
\hline İstanbul & 1.1 & 0.8 & 0.5 & 34.5 & 37.3 & 37.5 & 4.9 & 4.3 & 4.3 & 52.9 & 53.6 & 52.4 & 4.3 & 3.6 & 3.8 \\
\hline İzmir & 10.4 & 9.2 & 7.5 & 29.8 & 31.7 & 29.5 & 5.6 & 5.2 & 3.7 & 48.1 & 46.5 & 47.9 & 2.7 & 2.8 & 3.0 \\
\hline
\end{tabular}

Source:

Authors' computations using data provided by the Turkish Statistical Institute (Prime Ministry, the Republic of Turkey). 
Table 4

Real GDP in Key Migrant Magnets: Sectoral Annual Growth Rates (\%)

\begin{tabular}{|c|c|c|c|c|c|c|c|c|c|c|c|c|}
\hline & \multicolumn{2}{|c|}{ Agriculture } & \multicolumn{2}{|c|}{ Industry } & \multicolumn{2}{|c|}{ Construction } & \multicolumn{2}{|c|}{ All Services } & \multicolumn{2}{|c|}{$\begin{array}{c}\text { Hotel and } \\
\text { Restaurant } \\
\text { Services }\end{array}$} & \multicolumn{2}{|c|}{$\begin{array}{l}\text { Total Real } \\
\text { GDP }\end{array}$} \\
\hline & $\begin{array}{l}1990- \\
1995\end{array}$ & $\begin{array}{l}1995- \\
2000\end{array}$ & $\begin{array}{l}1990- \\
1995\end{array}$ & $\begin{array}{l}1995- \\
2000\end{array}$ & $\begin{array}{l}1990- \\
1995\end{array}$ & $\begin{array}{l}1995- \\
2000\end{array}$ & $\begin{array}{l}1990- \\
1995\end{array}$ & $\begin{array}{l}1995- \\
2000\end{array}$ & $\begin{array}{l}1990- \\
1995\end{array}$ & $\begin{array}{l}1995- \\
2000\end{array}$ & $\begin{array}{l}1990- \\
1995\end{array}$ & $\begin{array}{l}1995- \\
2000\end{array}$ \\
\hline Turkey & 0.6 & 1.7 & 4.5 & 4.0 & 1.6 & 0.5 & 3.7 & 4.3 & 4.4 & 5.3 & 3.2 & 3.9 \\
\hline Adana & 2.9 & -4.3 & 3.3 & 2.7 & -1.9 & -5.7 & 0.3 & 3.2 & 0.4 & 3.9 & 1.5 & 1.9 \\
\hline Ankara & -1.1 & 3.4 & 3.4 & 3.6 & 1.7 & 1.5 & 3.5 & 3.7 & 4.4 & 4.5 & 3.3 & 4.3 \\
\hline Antalya & 6.5 & 0.2 & 4.9 & 2.7 & 3.3 & -1.4 & 6.4 & 4.3 & 6.9 & 6.2 & 6.0 & 2.9 \\
\hline Bilecik & 2.3 & 0.3 & 11.1 & 0.4 & 6.7 & 3.5 & 6.0 & 1.4 & 2.0 & 3.4 & 7.7 & 0.9 \\
\hline Bursa & -1.7 & -1.6 & 5.6 & 6.0 & 2.6 & -3.1 & 4.2 & 5.7 & 5.6 & 4.6 & 3.5 & 4.9 \\
\hline Mersin & -2.1 & 8.6 & 2.9 & -0.7 & 0.9 & -10.5 & 4.8 & 3.4 & 4.7 & 3.3 & 2.8 & 2.7 \\
\hline İstanbul & -0.6 & -8.0 & 5.9 & 4.4 & 1.3 & 4.3 & 4.5 & 3.8 & 0.8 & 5.1 & 4.2 & 4.3 \\
\hline İzmir & 1.9 & -1.5 & 5.8 & 1.3 & 2.6 & -3.6 & 3.7 & 3.4 & 4.5 & 4.7 & 4.4 & 2.8 \\
\hline Kocaeli & 2.7 & -0.4 & 4.0 & 1.1 & 1.1 & 0.8 & 5.0 & 4.1 & 3.7 & 4.1 & 4.4 & 2.9 \\
\hline Muğla & 5.9 & -1.3 & 1.8 & 15.6 & -2.2 & 2.0 & 5.5 & 6.4 & 8.9 & 9.0 & 4.5 & 6.4 \\
\hline Tekirdağ & -2.4 & 4.0 & 8.2 & 12.4 & 1.9 & -3.3 & 3.9 & 6.3 & 5.2 & 4.6 & 4.0 & 7.7 \\
\hline
\end{tabular}

Source:

Authors' computations using data provided by the Turkish Statistical Institute (Prime Ministry, the Republic of Turkey). 
Table 5

Characteristics of Immigrants in Antalya and Muğla from Top Origins

\begin{tabular}{|l|c|c|c|c|c|c|c|c|}
\hline \multirow{2}{*}{ Origin } & \multicolumn{2}{|c|}{$\begin{array}{c}\text { Proportion of } \\
\text { immigrants (\%) }\end{array}$} & \multicolumn{2}{c|}{$\begin{array}{c}\text { Median age } \\
\text { (years) }\end{array}$} & \multicolumn{2}{c|}{$\begin{array}{c}\text { Proportion of } \\
\text { females (\%) }\end{array}$} & \multicolumn{2}{c|}{$\begin{array}{c}\text { Mean years of } \\
\text { schooling (years) }\end{array}$} \\
\cline { 2 - 9 } & ANT. & MUĞ. & ANT. & MUĞ. & ANT. & MUĞ. & ANT. & MUĞ. \\
\hline İstanbul & 11.4 & 14.9 & 30.5 & 33.8 & 46.1 & 42.5 & 8.2 & 9.3 \\
\hline Kocaeli & 1.8 & 3.8 & 29.5 & 27.8 & 47.7 & 43.6 & 8.1 & 8.9 \\
\hline Ankara & 9.1 & 7.1 & 29.0 & 29.5 & 48.0 & 44.0 & 8.7 & 9.8 \\
\hline İzmir & 3.8 & 10.1 & 27.0 & 28.1 & 46.0 & 42.9 & 8.8 & 8.7 \\
\hline Aydın & 1.1 & 6.3 & 25.8 & 25.6 & 47.1 & 42.3 & 7.8 & 6.7 \\
\hline Mersin & 3.1 & 1.7 & 25.1 & 24.5 & 44.6 & 36.4 & 7.0 & 7.9 \\
\hline Adana & 3.1 & 2.2 & 25.3 & 25.1 & 42.0 & 32.4 & 7.1 & 7.9 \\
\hline Hatay & 2.7 & 2.2 & 24.1 & 23.4 & 39.5 & 32.7 & 6.8 & 7.4 \\
\hline Denizli & 1.4 & 3.8 & 24.9 & 24.7 & 46.9 & 44.4 & 7.5 & 6.7 \\
\hline Afyon & 2.0 & 1.3 & 25.5 & 24.8 & 46.9 & 37.3 & 7.2 & 7.6 \\
\hline Burdur & 3.9 & 0.7 & 26.0 & 24.5 & 50.3 & 50.8 & 7.1 & 7.3 \\
\hline Isparta & 4.2 & 0.7 & 25.6 & 24.7 & 48.3 & 41.1 & 7.4 & 9.5 \\
\hline Konya & 5.7 & 1.9 & 25.8 & 24.4 & 45.8 & 39.3 & 6.9 & 7.9 \\
\hline Diyarbakır & 1.9 & 1.4 & 23.5 & 23.9 & 39.3 & 28.5 & 5.8 & 6.7 \\
\hline Van & 1.5 & 2.0 & 22.6 & 22.4 & 31.4 & 19.5 & 5.5 & 5.2 \\
\hline All provinces & 100.0 & 100.0 & 26.1 & 26.8 & 44.3 & 38.9 & 7.5 & 8.1 \\
\hline
\end{tabular}


Notes:

Figures given are for immigrants 5 years of age and older. In the computation of mean years of schooling for each province, 15, 11, 8, and 5 years of schooling are attributed, respectively, to university, high school, middle school, and primary school graduates in the province. Two years- worth of schooling is attributed to those who are literate but not a graduate of any school. Children under age six are omitted in computing the mean.

Source:

Authors' computations using unpublished data provided by the Turkish Statistical Institute (Prime Ministry, the Republic of Turkey). 
Table 6

Labor Market Status: Immigrants in Antalya and Muğla from Top Origins

\begin{tabular}{|l|c|c|c|c|c|c|c|c|}
\hline \multirow{2}{*}{ Origin } & \multicolumn{2}{c|}{$\begin{array}{c}\text { Not in labor force } \\
(\%)\end{array}$} & \multicolumn{2}{|c|}{$\begin{array}{c}\text { Employed } \\
(\%)\end{array}$} & \multicolumn{2}{c|}{$\begin{array}{c}\text { Unemployed } \\
(\%)\end{array}$} & \multicolumn{2}{c|}{$\begin{array}{c}\text { Unemployment } \\
\text { rate }\end{array}$} \\
\cline { 2 - 9 } & ANT. & MUĞ. & ANT. & MUĞ. & ANT. & MUĞ. & ANT. & MUĞ. \\
\hline İstanbul & 42.4 & 32.6 & 50.3 & 62.4 & 7.4 & 5.0 & 12.8 & 7.4 \\
\hline Kocaeli & 47.9 & 35.0 & 44.8 & 60.8 & 7.3 & 4.2 & 14.1 & 6.4 \\
\hline Ankara & 41.2 & 32.1 & 52.1 & 63.2 & 6.7 & 4.7 & 11.4 & 7.0 \\
\hline İzmir & 36.6 & 31.4 & 56.3 & 64.2 & 7.1 & 4.3 & 11.2 & 6.3 \\
\hline Aydın & 36.8 & 24.8 & 57.1 & 72.1 & 6.1 & 3.1 & 9.6 & 4.1 \\
\hline Mersin & 31.4 & 28.3 & 62.3 & 67.4 & 6.2 & 4.3 & 9.1 & 6.0 \\
\hline Adana & 33.7 & 26.4 & 60.0 & 68.5 & 6.2 & 5.0 & 9.4 & 6.8 \\
\hline Hatay & 29.8 & 30.0 & 64.6 & 66.3 & 5.6 & 3.6 & 8.0 & 5.2 \\
\hline Denizli & 35.3 & 28.6 & 60.0 & 68.3 & 4.8 & 3.0 & 7.4 & 4.2 \\
\hline Afyon & 39.7 & 24.4 & 54.6 & 73.1 & 5.7 & 2.5 & 9.4 & 3.3 \\
\hline Burdur & 41.7 & 32.6 & 53.1 & 63.4 & 5.2 & 4.0 & 9.0 & 5.9 \\
\hline Isparta & 34.8 & 29.4 & 59.4 & 64.2 & 5.7 & 6.4 & 8.8 & 9.1 \\
\hline Konya & 36.6 & 26.8 & 57.7 & 69.3 & 5.7 & 3.9 & 9.0 & 5.3 \\
\hline Diyarbakır & 36.9 & 16.9 & 56.9 & 80.0 & 6.1 & 3.1 & 9.7 & 3.7 \\
\hline Van & 30.0 & 13.0 & 64.1 & 83.2 & 5.9 & 3.8 & 8.4 & 4.4 \\
\hline All provinces & 37.2 & 28.6 & 56.6 & 67.3 & 6.2 & 4.2 & 9.8 & 5.8 \\
\hline
\end{tabular}


Notes:

Not in Labor Force, Employed and Unemployed are as a proportion of all immigrants, 12 years of age or older. Unemployment rate is as proportion of the Labor Force.

Source:

Authors' computations using unpublished data provided by the Turkish Statistical Institute (Prime Ministry, the Republic of Turkey). 
Table 7

Reason for Non-participation in Labor Force: Immigrants in Antalya and Muğla from Top Origins

\begin{tabular}{|l|c|c|c|c|c|c|c|c|}
\hline \multirow{2}{*}{ Origin } & \multicolumn{2}{|c|}{ Student (\%) } & \multicolumn{2}{c|}{ Retired (\%) } & \multicolumn{2}{c|}{ Housewife (\%) } & \multicolumn{2}{c|}{ Discouraged (\%) } \\
\cline { 2 - 10 } & ANT. & MUĞ. & ANT. & MUĞ. & ANT. & MUĞ. & ANT. & MUĞ. \\
\hline İstanbul & 26.6 & 29.1 & 21.9 & 30.1 & 43.6 & 34.0 & 4.5 & 3.5 \\
\hline Kocaeli & 30.4 & 30.2 & 23.4 & 13.1 & 39.7 & 50.8 & 4.9 & 4.5 \\
\hline Ankara & 27.8 & 30.8 & 21.9 & 26.9 & 43.4 & 34.6 & 2.7 & 5.1 \\
\hline İzmir & 35.7 & 37.9 & 14.9 & 14.2 & 40.3 & 35.8 & 5.3 & 4.8 \\
\hline Aydın & 40.9 & 33.7 & 11.4 & 8.4 & 41.3 & 48.2 & 3.8 & 4.5 \\
\hline Mersin & 31.9 & 48.5 & 7.5 & 6.1 & 50.0 & 35.3 & 6.4 & 6.3 \\
\hline Adana & 32.1 & 45.1 & 9.1 & 8.8 & 49.1 & 39.5 & 6.3 & 4.3 \\
\hline Hatay & 32.7 & 58.6 & 7.1 & 3.3 & 50.0 & 29.6 & 6.1 & 5.8 \\
\hline Denizli & 38.2 & 38.9 & 11.2 & 10.2 & 45.4 & 42.1 & 3.2 & 4.0 \\
\hline Afyon & 28.5 & 44.3 & 12.0 & 8.9 & 51.4 & 39.7 & 5.6 & 4.6 \\
\hline Burdur & 26.0 & 45.3 & 12.5 & 5.8 & 55.2 & 41.9 & 3.9 & 3.5 \\
\hline Isparta & 30.3 & 38.1 & 12.5 & 13.1 & 49.9 & 36.2 & 5.5 & 9.4 \\
\hline Konya & 29.5 & 38.5 & 11.3 & 5.2 & 51.5 & 47.5 & 5.3 & 5.7 \\
\hline Diyarbakır & 27.3 & 31.6 & 4.5 & 5.7 & 57.2 & 52.9 & 5.3 & 5.2 \\
\hline Van & 29.8 & 40.1 & 5.9 & 3.2 & 52.0 & 44.4 & 10.3 & 9.6 \\
\hline All provinces & 30.0 & 37.9 & 13.7 & 14.3 & 48.2 & 39.5 & 3.5 & 4.8 \\
\hline
\end{tabular}


Notes:

All figures are as a proportion of immigrants aged 12 and over who are not in the labor force. Discouraged workers are those who would like to be employed but did not apply for a job during the previous three months

Source:

Authors' computations using unpublished data provided by the Turkish Statistical Institute (Prime Ministry, the Republic of Turkey). 
Table 8

Sectoral Distribution of Employment: Immigrants in Antalya and Muğla from Top Origins (\%)

\begin{tabular}{|c|c|c|c|c|c|c|c|c|c|c|c|c|}
\hline \multirow[t]{2}{*}{ Origin } & \multicolumn{2}{|c|}{ Agriculture } & \multicolumn{2}{|c|}{ Manufacturing } & \multicolumn{2}{|c|}{ Construction } & \multicolumn{2}{|c|}{$\begin{array}{c}\text { Public, social } \\
\& \\
\text { personal } \\
\text { Services }\end{array}$} & \multicolumn{2}{|c|}{$\begin{array}{c}\text { Wholesale } \\
\& \\
\text { retail trade }\end{array}$} & \multicolumn{2}{|c|}{$\begin{array}{c}\text { Restaurants } \\
\& \\
\text { hotels }\end{array}$} \\
\hline & ANT. & MUĞ. & ANT. & MUĞ. & ANT. & MUĞ. & ANT & MUĞ. & ANT. & MUĞ. & ANT. & MUĞ. \\
\hline İstanbul & 19.1 & 31.9 & 8.7 & 4.9 & 5.3 & 5.0 & 19.8 & 24.5 & 16.5 & 9.8 & 15.2 & 13.1 \\
\hline Kocaeli & 18.4 & 16.1 & 5.4 & 3.4 & 8.1 & 3.9 & 30.9 & 60.2 & 10.8 & 5.3 & 15.0 & 5.8 \\
\hline Ankara & 16.3 & 23.1 & 6.0 & 4.2 & 6.3 & 6.6 & 30.9 & 32.9 & 11.6 & 6.1 & 15.1 & 12.4 \\
\hline İzmir & 14.6 & 14.6 & 7.6 & 6.5 & 4.2 & 5.8 & 30.3 & 24.6 & 12.9 & 11.5 & 18.1 & 16.7 \\
\hline Aydun & 21.2 & 29.4 & 3.2 & 7.9 & 7.1 & 9.8 & 24.1 & 18.3 & 11.4 & 8.2 & 20.9 & 17.7 \\
\hline Mersin & 24.8 & 24.8 & 9.2 & 7.4 & 8.0 & 7.3 & 19.6 & 29.7 & 7.2 & 5.6 & 24.4 & 22.3 \\
\hline Adana & 17.6 & 16.4 & 6.5 & 8.3 & 9.1 & 13.5 & 19.8 & 25.4 & 9.8 & 6.6 & 30.1 & 22.9 \\
\hline Hatay & 18.4 & 18.4 & 8.4 & 7.9 & 10.6 & 12.5 & 15.8 & 23.3 & 9.8 & 4.8 & 31.0 & 26.5 \\
\hline Denizli & 30.9 & 35.7 & 6.0 & 7.0 & 6.4 & 7.2 & 24.6 & 18.3 & 7.2 & 8.3 & 12.1 & 16.4 \\
\hline Afyon & 27.7 & 27.1 & 8.0 & 15.5 & 8.1 & 10.4 & 23.4 & 23.7 & 8.0 & 4.9 & 17.2 & 11.4 \\
\hline Burdur & 30.9 & 32.0 & 7.9 & 5.1 & 5.4 & 5.4 & 23.6 & 28.7 & 8.2 & 9.6 & 13.6 & 10.8 \\
\hline Isparta & 34.4 & 34.4 & 6.2 & 3.4 & 4.0 & 6.0 & 21.9 & 41.1 & 8.0 & 4.0 & 16.2 & 12.0 \\
\hline Konya & 29.9 & 21.2 & 7.4 & 8.1 & 7.7 & 10.2 & 19.7 & 31.0 & 10.2 & 6.4 & 18.3 & 14.4 \\
\hline Diyarbakır & 13.9 & 21.7 & 3.7 & 2.4 & 20.6 & 20.1 & 26.9 & 29.8 & 6.6 & 3.3 & 22.2 & 16.8 \\
\hline Van & 9.6 & 19.3 & 3.9 & 2.0 & 51.1 & 53.7 & 19.0 & 12.9 & 4.2 & 1.9 & 8.9 & 7.7 \\
\hline $\begin{array}{l}\text { All } \\
\text { provinces }\end{array}$ & 20.6 & 22.7 & 6.3 & 5.7 & 10.5 & 11.0 & 24.7 & 28.3 & 9.8 & 7.1 & 19.2 & 15.4 \\
\hline
\end{tabular}


Notes:

All figures are as a proportion of immigrants age 12 and over who are employed. Sectors listed are not exhaustive and includes only the main ones employing immigrants. Consequently, row totals do not add up to 100. Agriculture includes hunting, forestry and fishing. Public, social and personal services cover employment in government bureaucracy (including military and police), in health, education, environmental, and cultural institutions, as well employment as repairmen, gardener, barber, dry cleaner, maid, babysitter, accountant, etc.

Source:

Authors' computations using unpublished data provided by the Turkish Statistical Institute (Prime Ministry, the Republic of Turkey). 
Table 9

Estimated Regression Equations

\begin{tabular}{|c|c|c|c|c|}
\hline \multirow{2}{*}{ Variables } & \multicolumn{2}{|c|}{ OLS Regressions } & \multicolumn{2}{|c|}{ Robust Regressions } \\
\hline & ANTALYA & MUĞLA & ANTALYA & MUĞLA \\
\hline CONSTANT & $\begin{array}{c}1.730 \\
(0.057)\end{array}$ & $\begin{array}{l}-2.236 \\
(0.073)\end{array}$ & $\begin{array}{l}1.454 \\
(0.03)\end{array}$ & $\begin{array}{l}-1.508 \\
(0.149)\end{array}$ \\
\hline $\begin{array}{l}\text { RESIDENT } \\
\text { POPULATION }\end{array}$ & $\begin{array}{c}0.486 \\
(0.000)\end{array}$ & $\begin{array}{c}0.883 \\
(0.000)\end{array}$ & $\begin{array}{c}0.521 \\
(0.000)\end{array}$ & $\begin{array}{r}0.605 \\
(0.000)\end{array}$ \\
\hline DISTANCE & $\begin{array}{l}-0.610 \\
(0.000)\end{array}$ & $\begin{array}{l}-0.493 \\
(0.000)\end{array}$ & $\begin{array}{l}-0.626 \\
(0.000)\end{array}$ & $\begin{array}{l}-0.408 \\
(0.000)\end{array}$ \\
\hline $\begin{array}{l}\text { RELATIVE } \\
\text { UNEMPLOYMENT }\end{array}$ & $\begin{array}{c}0.454 \\
(0.000)\end{array}$ & $\begin{array}{c}0.281 \\
(0.065)\end{array}$ & $\begin{array}{c}0.448 \\
(0.000)\end{array}$ & $\begin{array}{c}0.326 \\
(0.010)\end{array}$ \\
\hline $\begin{array}{l}\text { PAST } \\
\text { MIGRATION }\end{array}$ & $\begin{array}{c}0.420 \\
(0.000)\end{array}$ & $\begin{array}{c}0.037 \\
(0.064)\end{array}$ & $\begin{array}{r}0.392 \\
(0.000)\end{array}$ & $\begin{array}{c}0.378 \\
(0.000)\end{array}$ \\
\hline EARTHQUAKE & $\begin{array}{c}0.026 \\
(0.000)\end{array}$ & $\begin{array}{c}0.013 \\
(0.045)\end{array}$ & $\begin{array}{c}0.018 \\
(0.000)\end{array}$ & $\begin{array}{c}0.017 \\
(0.003)\end{array}$ \\
\hline $\mathbf{R}^{2}$ & 0.93 & 0.87 & 0.96 & 0.92 \\
\hline
\end{tabular}


Notes:

All variables are in logarithms. For definitions of variables, see Section 3. The dependent variable in each regression is the number of people who migrated from province $i$ to province $j$ (Antalya or Muğla) during 1995-2000 ( $\mathrm{M}_{\mathrm{ij}}$ ). The OLS (Ordinary Least Squares) regressions are estimated, utilizing the REG procedure of SAS (2008) statistical package. Robust regressions are estimated using the same statistical package's ROBUSTREG procedure with the LTS (least trimmed squares) method and FWLS (final weighted least squares) option. The following observations are picked by the latter algorithm as outliers: Ankara, Bolu, Giresun, Hatay, Kahraman Maraş, Tunceli, Van and Yalova, in the Antalya equation, and Hakkâri and Kocaeli in the Muğla equation. The numbers in parantheses below the parameter estimates are the probabilities relevant to the t-test of whether the associated coefficient is equal to zero, in the case of first two columns, and to the corresponding chi-square test in the case of last two columns.

\section{Source:}

The data on the EARTHQUAKE $\left(\mathrm{Q}_{\mathrm{i}}\right)$ variable is obtained from the General Directorate of Disaster Affairs (Ministry of Public Works and Settlement, the Republic of Turkey). The DISTANCE $\left(\mathrm{D}_{\mathrm{ij}}\right)$ values are taken from the General Directorate of Highways (Ministry of Transport and Communication, the Republic of Turkey). The source of data for all other variables is the Turkish Statistical Institute (Prime Ministry, the Republic of Turkey). The RESIDENT POPULATION in $1995\left(\mathrm{P}_{\mathrm{i}}\right)$ figures are obtained by deducting from the resident population of province $\mathrm{i}$ in 2000 , the total in-migration into the province, and adding total outmigration from the province during 1995-2000. To approximate the PAST MIGRATION $\left(\mathrm{H}_{\mathrm{ij}}\right)$ figures, which are not readily available, the product of $\mathrm{M}_{\mathrm{ij}}$ and the proportion of native born in province $i$ is deducted from the number of people living in province $j$ in 2000 who were born in province i. In a few cases where the resulting figure turned out to be negative, it is taken as 0.000001 instead. The latter is not given the value of zero, so that logarithms can be taken. For the same reason, for those provinces not affected by the 1999 earthquakes, $\mathrm{Q}_{i}$ is taken as 0.000001 rather than zero. 